\title{
Implementation of Online Learning during the Covid-19 Pandemic on Madura Island, Indonesia
}

\author{
Priyono Tri Febrianto* \\ Universitas Trunojoyo, Bangkalan, East Java Province, Indonesia \\ https://orcid.org/0000-0002-0753-1037 \\ Siti Mas'udah and Lutfi Apreliana Megasari \\ Universitas Airlangga, Surabaya, East Java Province, Indonesia \\ https://orcid.org/0000-0001-8715-4448 \\ https://orcid.org/0000-0001-5689-7839
}

\begin{abstract}
This study aimed to determine the online learning process and the associated obstacles experienced by students. With the background of the ongoing Covid-19 pandemic outbreak, this study sought to uncover what social constructions the students engage in related to the new policy for online learning that has recently been enforced by the Indonesian government. A quantitative study was conducted with a descriptive research approach. There were 274 college student respondents from Madura, Indonesia. This study found that not all of the students prefer online learning, inclusive of expressing their disapproval that online learning is effective. Social, economic and cultural factors are important indicators that online learning has not been able to be effectively carried out in a number of regions in Indonesia. Rural communities are not ready to welcome the latest learning methods and they are still comfortable using conventional methods. Online learning on Madura Island is not only constrained by technical problems and facilities but also by the human resources that need to be encouraged to accept the latest learning models. Students consider this learning model to not be beneficial due to the presence of several obstacles, including the geographical area. This is because rural areas make it difficult to access the internet. They also have to buy an internet quota. Internet access in some applications requires a large quota so this becomes problem for some students, especially for those who come from lower-middle income families. Therefore the availability of supporting facilities and infrastructure as well as the facilitated internet access among rural communities, financial assistance and the socialisation of the importance of online learning is necessary.
\end{abstract}

Keywords: Online learning; Students; COVID-19; Conventional learning; Obstacles

\footnotetext{
"Corresponding author: Priyono Tri Febrianto; Email: priyono.febrianto@trunojoyo.ac.id
} 


\section{Introduction}

Learning media and systems are starting to shift from conventional learning to the latest learning process by utilising technological assistance. Schools and teachers strive to incorporate digital learning media in order to create a more effective and applicable learning environment. In the 20th century, the digital transformation has spread to almost all spaces and fields, including education. Known as e-learning, online learning media creates community spaces among the students that are not merely educational but also entertainment. This is because they explore the student's digital literacy (Tan, 2013). Through the benefits of social media and various platforms, students and teachers have the opportunity to optimise the learning process. Previous studies have suggested that e-learning is focused on the students' understanding of collaborative work such as how to build meaning, how to negotiate together and how to understand each other (support) in a learning process that is conducted at a distance (Friedman \& Friedman, 2020).

E-learning is also used to maximise the learning process even though it is carried out without face-to-face meetings. This type of learning is an alternative to accommodating traditional forms of learning. E-learning is considered to be quite effective because it helps the teachers to build virtual classrooms in accordance with the conditions of learning in the classroom (Putranti, 2013). Typically, teachers in developed countries optimise their use of the current digital platforms in order to keep up with the platforms used by the students and to create comfortable learning spaces. Learning media focuses on how shared spaces can be used to communicate ideas and produce specific learning content so as to improve the skills of both the students and teachers (Hansch et al., 2015).

A study conducted by Donelly (2006) stated that e-learning is a medium where face-to-face learning interactions are used to create a virtual discussion area. Through e-learning, teachers and students can remove the place and time barriers that can be a learning constraint. Learning can also be carried out by utilising social media such as Facebook, Youtube, Twitter, Instagram, Blogger and Quora by and for the students. E-learning also offers networking ease and knowledge sharing opportunities but it has negative effect in terms of potentially wasting time (Salmon et al., 2015; Hollis \& Was, 2016; Brownson, 2014).

Moreover, the positive aspects of online learning allow students with limited time available and geographical distance to get an education. Meanwhile, the negative aspect is the difference in competition because electronic communication is not natural when creating learning spaces (Kock, Verville, \& Garza, 2017). Through e-learning, the teachers are not required to meet with the students in order to be able to create a learning space. However, by using one of the platforms available, learning space discussions can occur easily. In addition, e-learning offers flexible hours as the teachers can send assignments at any time and from anywhere. If effective teaching and learning practices can be 
performed automatically, this can support the process of improving the learning practices (Agostinho et al., 2011).

A study conducted by Herayanti, Fuaddunnazmi and Habibi (2015) determined that the benefits of e-learning including overcoming the limitations of the faceto-face lesson frequency between the students and teachers through the features of online platforms. Learning spaces that are usually in one room can now be replaced by online learning. It is also beneficial for the teachers if they give additional lessons. Previous studies have suggested that e-learning makes it easier for the students to share resources, record the learning material, and feel comfort when engaging in the discussion. However, the student's ability to understand the lessons varies because e-learning is not as natural as face-to-face learning (Dabbagh \& Kitasantas, 2012). E-learning is not applicable in all areas. In remote areas, internet signal constraints and a lack of access and tools for online learning make it difficult. Moreover, e-learning in several places is not necessarily considered able to replace face-to-face learning.

In e-learning, teachers are not only engaging in a discussion about the study materials resulting in the students doing assignments as in the various levels of education including elementary through to high school. Learning also requires comprehensive content. Some of the content in online learning in the form of text, images, video and audio requires the students to use communication and information technology independently in a structured and valid learning syllabus (Prastiyo, Djohar \& Purnawan, 2018; Hartsell \& Yuen, 2006; KuangChih \& Kriegman, 2018). Some subjects need content to support the learning that takes place. Images, videos and audio are needed to support their learning. This can be carried out through online learning.

On the other hand, social media like Youtube can be an alternative learning media. This video-based form of social media brings in great benefits when it is part of the learning process. A study conducted by Kruse and Veblen (2012) found that the utilisation of Youtube for digital learning brings in opportunities for educators to increase the intensity of uploading videos to Youtube. This supports a participatory culture in terms of making circulatory videos, images and allowing for user expressions. This indicates that social media is not merely used as a means of expression. It is also used as part of an effective learning process. Previous studies have found that schools and universities use Youtube as a relevant learning medium because it is not only an academic learning medium. It is also an information and entertainment search tool (Moghavvemi, 2018; Chau, 2010; Lin \& Polaniecki, 2009).

Even though e-learning is the latest learning system in use, not everyone accepts it well. The benefits of online learning face participation injustice because some teachers doubt the use of online media as a learning tool (Nacu et al., 2014). Teachers who are of the "baby boomer" generation are less able to use online media in the learning process. On the other hand, some social media also has shortcomings when it is used as learning media. Previous studies have mentioned that some educational institutions use social media such as Facebook 
to send the students work and promote it. However, there are limitations in terms of Facebook's ability to make albums and transmitting the student's assessment scores (Whittaker, Howarth \& Lymn, 2014; Madge et al., 2009; Selwyn, 2009).

Even so, teachers, academics and lecturers still try to use digital platforms as a learning tool. A study conducted by Greenhow and Lewin (2015) pointed out that social media - as a form of online learning media - has the potential to bridge the formal and informal aspects through a participatory digital culture where young people easily adopt the role of consumers. In this case, social media is used in such a way as to support learning. For example, a teacher can use applications like Zoom or Instagram Live video to broadcast a discussion. In addition, the use of e-learning has penetrated smartphones that have eventually become a form of flexible learning media because they are integrated with the internet and all relevant applications (Martono \& Nurhayati, 2014; Arista \& Kuswanto, 2018; Irwansyah et al., 2017).

Thoms and Eryilmaz's study (2014) mentioned that students experience higher interactions when using online learning media including sharing it with their social communities and a high level of satisfaction. This makes digital learning more interesting than face-to-face learning. This confirms that online learning is proven to have a positive influence on the students. By joining social media, students not only attend lessons but they also interact with fellow users, including their school friends. Previous studies have found that digital learning media offers an easier approach with a focus on content delivery and business as well as the ability to challenge the traditional learning models used in the classes (Yuan, Powell \& Olivier, 2014; Liu, 2005).

On the other hand, digital learning does bring in significant benefits. Digital learning through videos is very effective because of the aspects of flexibility which can help with the depth and retention of knowledge, in addition to motivating an interest in learning. It can be used to illustrate the relevance of concepts (Thomson \& Bridgstock, 2014). Not only on Youtube, but various other social media currently also offer video-based and non-video views. In fact, both the students and teachers can choose from various social media platforms. On the other hand, digital media constitutes the acceptance that there is a high prevalence of technology use among students including learning applications, Google, podcasts and e-books (Gutmann et al., 2015; Bolliger, Supanakorn, \& Boggs, 2010; Annad, 2008).

A study conducted by Megan (2015) found that various universities are trying to develop the digital skills of prospective graduates through learning media in order to increase their resources. This is where social media can be used to enhance the positive online reputation and increase the opportunities for posttertiary employment. This implies that the students are prepared for both expertise based on their knowledge and mastering of technology and information for the implementation of the aforementioned knowledge. Digital learning can facilitate the students in being creative through the use and creation 
of interesting content, both informal and extracurricular, while providing competitive advantages. However, this can cause disparities (Brown, Czerniewicz, \& Noakes, 2015; Peppler \& Kafai, 2007; Greenhow \& Robelia, 2009).

A study conducted by Kirkwood and Price (2013) explained that e-learning provides a highly structured context that engages the students successfully and supports the achievement of their skills, problem solving and teamwork. By using various platforms including social media, teachers can provide case studies within the learning material. Furthermore, digital media also provides space to work as a team.

Although online learning is predicted to be a very effective learning system, it still has weaknesses. The weaknesses include the correlation between course structure and dialogue, therefore increasing the structure alone reduces the dialogue. Conversely, increasing the dialogue reduces the structure present in distance education (Horzum, 2015; Bound, 2010; Power, 2008). Therefore not all of the learning materials can be applied through distance learning.

This study has raised the issue of online learning among the students in Madura, East Java. It used the background of the Covid-19 pandemic outbreak because the learning process in Indonesia has recently shifted to digital learning. Digital learning in Indonesia still faces obstacles because of the limited internet access and supporting infrastructure. This study is important because not all regions in several countries around the world have adequate enough access to the internet to apply online learning.

\section{Literature Review}

The implementation of online learning is supported by several theories. Driver and Bell (in Susan \& Tony, 1995) explained the theory of constructivism. Constructivism theory is a view of constructivism in which the students have a goal, can be involved in their learning and are able to carry out or construct knowledge more individually. Learning activities in the classroom not only play a role in increasing the students' knowledge but they also involve setting the situation in the classroom. In addition, a curriculum can contain learning tools, materials and resources.

The essence of constructivism theory is that the students must discover and transform complex information by themselves, check for new information using old rules and revise it if the rules are no longer appropriate (Trianto, 2007). This is fully contained in online learning where students have the freedom to obtain information and organise their own learning. Students are no longer assisted by the teacher face-to-face when solving problems but they are encouraged to explore and solve problems or problems are assigned independently.

Sagala (2008) also explains constructivism theory. The essence is that the students must discover and transform the information from the teacher 
independently. The teacher's job is to facilitate the students in obtaining and providing the information that will become relevant knowledge.

Learning according to constructivism theory is a process of forming knowledge. This formation is done by the students themselves. All of the learning processes are directed to the students as the learning subjects so then students can be independent when developing their knowledge, drafting concepts, actively thinking, and giving meaning to something that is learned. The teacher acts as a designer and creates an environment that makes learning possible.

Meanwhile, the behaviourist learning theory explains that in learning, there are changes in behaviour (Farooq \& Javid, 2012). Online learning also provides a stimulus for the students to be actively involved in the learning process even though it is through virtual media. Changes also occur when conventional (faceto-face) learning switches to online learning, which causes major changes in the learning styles and systems.

In the learning theory of connectivism, this theory supports the existence of a new perspective on how learning can take place in a virtual space. This is in accordance with the concept of online learning where the virtual space is a place for learning activities where all involved are digitally connected to each other.

Rusman (2011) stated in his theory that the characteristics of online learning include interactivity, accessibility, and enrichment. Even though the students and teachers do not meet face-to-face, they can carry out the learning process interactively by maximising the use of technology. Learning can run through various applications such as the use of video or audio and message-based programs. Access to learning that is easily accessible can ultimately enrich the students' knowledge and the nature of education can be realised properly.

Meanwhile, the use of instructional media is an important aspect in the running of education. The theory of Heinich et al. (1982) states that teachers need to consider the selection of appropriate learning media for students in order to create successful learning activities including objectives, content, motivation, technicality, ownership, and instructions for use. Therefore the teachers really have to understand what media is right for the students because not all digital media can be accepted and run smoothly to go on to become a learning medium.

In addition, online learning is a learning system that is more open. It also fulfils the emotional needs of the students. Kaler (2012), in their learning needs theory, revealed that the learning needs of students and the online learning environment are the same. Students often feel bored in conventional learning because there is nothing new offered in face-to-face meetings. Through online learning, students encounter challenges and they get freedom and independence from learning online. 


\section{Research Methods}

A quantitative study was conducted using a descriptive research approach. The study was conducted using structured interviews with 274 college students from Bangkalan, Sampang, Pamekasan and Sumenep. The study took on the social setting of the Covid-19 pandemic because the learning system in Indonesia has been directed towards online learning, even though this type of learning process is considered by some parties to be not ready in several places in Indonesia.

The data collection was carried out by distributing questionnaires through a Google form that was sent to the students in remote areas on Madura. In addition to the survey data obtained from the Google form, this study also triangulated the data in order to reveal the reality of the study in more depth.

Data triangulation was conducting using in-depth interviews with the students, lecturers and parents of students who were the respondents in this study. Some of the in-depth interviews were conducted face-to-face with the informants while adhering to the health protocols by implementing social distancing and wearing masks. Some were carried out over the telephone because of the Covid19 pandemic in which some people only wanted to be interviewed by telephone.

The data obtained was then processed and categorised based on the topics studied. After that, the data was analysed, interpreted, dialogued and discussed using the theories and previous studies relevant to the research topic. The conclusions and recommendations are based on the results of this study.

\section{Results and Discussion}

\subsection{Student's Responses to Online Learning during the Covid-19 Pandemic}

Since the Covid-19 pandemic has exploded in various countries, this outbreak has disrupted many sectors including that of education. In Indonesia, the ongoing pandemic has a major impact and influence on the education sector. Schools and universities are temporarily closed to prevent widespread transmission. The government has then decided to replace the conventional learning system with learning from home using online media.

This study chose college students living in Madura, East Java as the respondents. The responses varied, ranging from liking to disliking online learning. While there is an ease in terms of the information technology that can be used to optimise learning, it turns out that online learning in some of the regions in Indonesia requires more serious handling to create a better learning climate. In fact, several Indonesians are not accustomed to using online media or digital media, including in the setting of education. The content presented on social media has not been able to be absorbed or even used to optimise education. So far, education in some of the regions of Indonesia is still conventional where the teachers explain things in front of the class. This condition strongly correlates with the gaps and inequalities found in the facilities in the country. Learning in Jakarta (capital of Indonesia) may be better and run well given all of the available facilities but learning in the outer and remote areas such as Papua, 
Maluku and the tip of Nusa Tenggara cannot enjoy such effective facilities and learning.

With the Covid-19 outbreak, people have been required to become able to follow the system set up by the government. In addition to learning through online media, students are also given access to learning through national television channels. However, this option is intended for elementary school students while the other levels depend on learning through the internet. Therefore society has no choice other than to follow the lessons on digital media.

The responses given by the participants regarding online learning varied. There were respondents who considered e-learning to be more effective and efficient because it has no time and place constraints. Table 1 shows several of the reasons why students like online learning. During the pandemic, they really took advantage and felt that the use of online media was very beneficial. This is also in accordance with Kaler's (2012) theory that students can lessen their boredom due to conventional learning. They are challenged by online learning.

Table 1: Reasons for Preferring Online Learning (N=274)

\begin{tabular}{|l|c|c|}
\hline \multicolumn{1}{|c|}{ Reasons for Preferring Online Learning } & Frequency & Percentage \\
\hline More effective & 40 & $14.60 \%$ \\
\hline More efficient & 69 & $25.18 \%$ \\
\hline Easier to conduct & 162 & $59.13 \%$ \\
\hline Easier to understand the learning material & 3 & $1.09 \%$ \\
\hline Total & 274 & $100.00 \%$ \\
\hline
\end{tabular}

Source: Primary data

Although online learning is the best choice and it is very beneficial for some students, there were respondents who claimed that e-learning is less enjoyable. One reason why they do not prefer e-learning is because they cannot afford to access the internet. It should be noted that not all Indonesians enjoy internet facilities. As said by Rin (age 20, a college student):

"Apart from being a pandemic reason, online learning also seems to be easier to put into practice. We have more study time and we can study freely at any time. If in class I only have to pay attention to the lecturers' explanations, with online learning, I have a lot of time reading books".

In this study, the college student respondents came from various regions in Madura Island. For some of the respondents from rural and remote areas, using the internet facilities is still difficult. Moreover, most of the students choose to go back to their hometowns and leave their rented house in the campus environment. While they can access $\mathrm{Wi}-\mathrm{Fi}$ and a fast internet network in the campus environment and rented houses, it is different when they return to their homes that are often located in rural areas. Apart from having to buy an internet quota, internet access in some of the applications requires a large quota. Therefore these factors inhibit the students from accessing e-learning, especially those who come from lower-middle income families. 
Table 2 shows that e-learning in Indonesia still faces some obstacles. The responses given by the respondents varied in terms of their dislike of online learning. Apart from being limited to internet access, they also feel that online learning is not as easy as conventional learning. Due to the habits of conventional learning, many people consider the lessons given through elearning to be less optimal.

Table 2: Reasons for Not Preferring Online Learning $(\mathrm{N}=274)$

\begin{tabular}{|l|c|c|}
\hline Reasons for Not Preferring Online Learning & Frequency & Percentage \\
\hline Too high of a cost to access the internet & 37 & $13.50 \%$ \\
\hline $\begin{array}{l}\text { Cannot understand the lessons through e- } \\
\text { learning because it is limited }\end{array}$ & 88 & $32.12 \%$ \\
\hline Uncomfortable because not face to face & 49 & $17.88 \%$ \\
\hline Burdens students with assignments & 100 & $36.50 \%$ \\
\hline Total & 274 & $100.00 \%$ \\
\hline
\end{tabular}

Source: Primary data

Students are accustomed to conventional learning that involves listening to their lecturers speaking in front of the class and writing on the board. This condition is not found during e-learning. Although applications such as Zoom offer share screen features, it cannot make the students feel as comfortable as studying in the conventional way does. In addition, there were also respondents who stated that online learning cannot take place optimally because it is different from faceto-face meetings. This is influenced by the habits of a society that still relies on face-to-face communication.

Some of the previous studies conducted in developed countries that have adopted online learning first, such as in the United States, initially experienced a number of doubts regarding cost, convenience, flexibility, and a lack of confidence in the abilities of the students. But at the end in 2011, education in America was innovated after considering the aspects of the delivery model, educational curriculum, the role of the faculty, student recruitment, and student support (Clerkin \& Simon, 2014). Meanwhile, research by Moore, Dickson-Deane and Galyen (2011) found that online learning systems and conventional learning in Europe and America have been run well.

Research by Crick et al. (2020) noted that the online learning switch that occurred during the Covid-19 pandemic suggests a much more positive attitude. Learning has more leverage and it is done more efficiently. However, this study also noted a number of concerns that could shift the role of the educational institutions, leading to a changing workload and job fragility.

Ahmad, Sosa and Musfy (2020) stated that online learning is indeed beneficial. But, on the subject of architecture and design, online learning faces major obstacles. The design of the architectural education institutions used in the United Arab Emirates during the Covid-19 pandemic experienced difficulties in terms of the teaching design without contacting the students. In addition, they 
feel that online learning is something that is forced on students. In contrast to Western societies that are accustomed to distance learning, the present study shows that some people on Madura Island still consider that distance learning makes it difficult to improve the quality of education. As said by Mar (age 21, a college student):

"Online learning imposes a variety of assignments on us. Study time is also not the same as on campus, so to make up for that shortcoming, our lecturers give more assignments than usual".

Distance learning is also interpreted as "self-study" by some of the students and instructors. For some of the lecturers and teachers, giving additional assignments is their way of optimising learning. This is considered to be a substitute material for the learning that takes place face to face. However, many people judge that this kind of learning is placing a burden on students. Online learning is judged not to provide convenience for students. Instead, they are burdened by the variety of assignments given to them by their lecturers.

On the other hand, the new methods applied during the outbreak were responded to by various respondents. Not all of the students like online learning that relies on certain applications. Some of them still like the conventional learning methods. As shown in Table 3, there are several methods that are preferred by the students on Madura Island. A study conducted by Kobayashi (2017) found that not all students understood and liked all of the different types of online learning application available. Some of the students do not prefer rich learning media. They prefer lean media in the form of online slide presentations recorded using internet-based audio.

Based on constructivism theory, online learning provides opportunities for the students to explore more knowledge independently. This can be seen from the students in Madura who stated that online learning provides freedom in learning and the students find it easy to access learning. They stated that their learning is efficient because it is not obstructed by place and time, which means that the students could more freely participate in learning.

Table 3: Preferred Method for Implementing Online Learning (N-274)

\begin{tabular}{|l|c|c|}
\hline \multicolumn{1}{|c|}{$\begin{array}{c}\text { Preferred method for implementing online } \\
\text { learning }\end{array}$} & Frequency & Percentage \\
\hline PowerPoint & 97 & $35.57 \%$ \\
\hline Module & 45 & $16.33 \%$ \\
\hline Video & 122 & $44.55 \%$ \\
\hline Assignment/Quiz & 10 & $3.55 \%$ \\
\hline Total & 274 & $100.00 \%$ \\
\hline
\end{tabular}

Source: Primary data

Table 3 shows that most of the respondents prefer video-based learning materials. Learning through a video is considered to be an effective and fun method. Apart from displaying images, video is a tool that can convey information because it contains both audio and visual elements. Youtube is one 
of the social media platforms that can be used to optimise online learning. As stated by Feb (age 38, a lecturer):

"Learning on our university uses Zoom as a medium. Even though sometimes I feel that there are a lot of challenges, this is quite helpful so that education can continue during a pandemic".

On the other hand, Powerpoint is still the learning method favoured by the respondents. PowerPoint offers an effective and efficient learning system because the lecturers can summarise the teaching materials used which can then be shared with students. However, PowerPoint can make the students when it comes lazy to finding other material or reading original sources.

A study conducted by Abrami et al (2011) stated that there are three types of interactions in online learning, namely student-student interactions, studentteacher interactions and student-content interactions. Student-content interactions include reading informational texts, using study guides, watching learning videos, interacting with multimedia, participating in simulations and doing assignments. In an online learning system, the teachers do not monitor as closely as in conventional learning in schools. However, the teachers are required to try to provide educational and fun teaching so then the online learning feels like learning directly from the teacher.

While e-learning abroad is easily accessible, it is different for Indonesians who live in remote areas who find it difficult. Not all learning in Indonesia can be conducted through face-to-face teaching and video conferencing. This is because there are many obstacles in terms of the supporting facilities such as the availability of personal computers and the internet networks. This makes online learning not so applicable in several regions in Indonesia, including in Madura.

Previous studies have explained that there is no significant difference between online learning and conventional learning (face-to-face). Online interaction fosters closeness and a better use of time to interact than face-to-face interactions (Fortune, Spielman \& Pangelinan, 2011; Schoenfeld-Tacher, McConnell, \& Graham, 2001; Rovai \& Jordan, 2004). However, this is clearly different from the results of this study. The respondents stated that conventional learning (face-toface) was better than online learning. This is inseparable from the various problems that we have mentioned above.

The use of digital media as an online learning tool can replace conventional learning. The online learning in this study is in accordance with Rusman's theory that online learning also implements interactivity, accessibility, and enrichment. Although most learning is done through Zoom videos, learning on Madura Island is still trying to be maximised. This is also in accordance with Heinich's theory that lecturers and educational institutions really need to consider what media is appropriate to use amidst the various obstacles. 
Table 4: Learning System Preferred by the Students ( $N=274)$

\begin{tabular}{|l|l|l|}
\hline \multicolumn{1}{|c|}{$\begin{array}{c}\text { Learning System Preferred by the } \\
\text { Students }\end{array}$} & \multicolumn{1}{c|}{ Frequency } & \multicolumn{1}{c|}{ Percentage } \\
\hline E-learning & 4 & $1.46 \%$ \\
\hline Conventional learning & 270 & $98.54 \%$ \\
\hline Total & 274 & $100.00 \%$ \\
\hline
\end{tabular}

Source: Primary data

Table 4 shows that most of the students prefer conventional learning rather than e-learning. This strengthens the assumption that certain regions in Indonesia, including Madura, are not ready for online-based learning. Conventional learning is still an optimal system because it has been used for years. Although the students are young people who are familiar with the latest gadgets and information technology, in reality, they have not been able to accept online learning well.

When examined further, the respondents in this study had important responses such as an inability to take advantage of the available opportunities properly. The education system around the world is slowly changing, with all of the changes being increasingly influential for various countries, including Indonesia. Online learning has been used in various countries around the world. Even one of the universities in Indonesia, the Indonesian Open University, has been using this method for a long time. However, this learning system faces many obstacles to the goal of being adopted by many students living in rural or remote areas.

A study conducted by Moran, Seaman and Tinti-Kane (2011) stated that digital learning media creates a business space for technology development companies that can offer effectiveness and efficiency through the technology used for learning to form a collaboration. Unfortunately, this has not been well-utilised by society. Various social media platforms and other applications are still limited in their use for communication.

On the other hand, the use of online media, which is expected to be an alternative to conventional learning, has not been able to be interpreted as a means of supporting the learning process. In online learning, students are asked to concentrate on the tasks given by the teacher. However, the use of the internet bothers them because they are involved in social media and other applications that make them want to play rather than learn (Hollis \& Was, 2016). This happens in all students from low levels of education through to tertiary education. On one occasion, the students forgot to study and chose to open other applications such as online games and social media.

Previous studies have suggested that digital learning media also uses social media applications such as Facebook, Twitter, Tumblr and Snapchat, which were originally social networks but are now fully utilised. This is because many people use the internet (Selwyn \& Stirling, 2015; Veletsianos, 2015; Junco, Heiberger \& Loken, 2010). This indicates that the synergy between the students and teachers can optimise the learning process. It should be noted that learning 
media is a form of social media application that has the user's characteristics. Facebook, for example, is used by baby boomers while Twitter is used by people of all ages. This indicates that teachers and students can collaborate when utilising social media so as to create a familiar learning space.

These things are different in Indonesia. Several universities in Indonesia provide a special platform to accommodate the students and lecturers so then they can meet in one place (the platform). The students and lecturers are required to use platforms that have been provided by the policy makers at the university. On another occasion, they used the Zoom application to discuss the lesson. This is different from other countries that use the latest social media as a discussion room. Some of the lecturers in Indonesia including Madura do not have social media, so this becomes an obstacle when the learning system is changed as suddenly as it happened during the Covid-19 pandemic.

Furthermore, the students' dislike of learning online is because the students are not familiar with online learning. Through online learning, new behaviours are formed. This is in accordance with behaviourism learning theory where learning creates behaviour change. In the end, students do not depend on the lecturers' explanations and they actively seek knowledge and develop insights through the digital media. On the other hand, this also relates to the theory of connectivist learning where digital learning also requires connectivity to achieve the learning goals.

Table 5: Emerging Impacts Related to Online Learning (N=274)

\begin{tabular}{|l|c|c|}
\hline Emerging Impacts Related to Online Learning & Frequency & Percentage \\
\hline Online learning is less effective & 194 & $70.80 \%$ \\
\hline Overall learning experience is distracted & 80 & $29.20 \%$ \\
\hline Total & 274 & $100.00 \%$ \\
\hline
\end{tabular}

Table 5 shows that the respondents admitted that online learning has weak points for them. Online learning is considered to be less effective because the students are accustomed to using conventional media. In addition, online learning is still considered not to be the best solution during the Covid-19 pandemic. Those who feel the convenience of face-to-face learning cannot completely turn to online learning suddenly. As stated by Nur (age 49, a lecturer):

"Online learning brings challenges for lecturers. Usually we can discuss in class for a long time and in an effective atmosphere. But online learning feels different because the discussion doesn't work as naturally as conventional learning".

Although online media facilitates student learning, the online presence still encounters obstacles because the process is not like a face-to-face meeting, and therefore it makes use of online discussion facilities, wikis, and a blog system (Yang et al., 2016). Some lecturers use the public discussion rooms available on several platforms. Lecturers who master the various social media platforms easily adapt and follow a changing learning system. Those who are tech savvy 
use social media like Youtube and Twitter as learning media. A study conducted by Batt and Cummins (2016) concluded that the social media platforms that can be used as digital learning media are Youtube and Facebook. This is because they are easy to use and familiar to almost everyone. In addition, education practitioners adopt social media to form an online community, especially on Twitter where online learning is easily digested because of the tweet/retweet facilities that are able to reach many people up to the point of trending (Shen, Kuo, \& Minh Ly, 2017).

The previous studies have explained that online learning media is easily accessible because almost every student or parents has a smartphone or laptop. They use networking and social media as an online learning method (Hamilton et al., 2016; Melhuish \& Falloon, 2010; Parker et al., 2011). The present study shows that some of the remote areas in Indonesia including Madura face many obstacles to implementing the online learning policies as confirmed by the government. In this case, this government needs to make a pretty hard effort to catch up with the learning system. The Covid-19 outbreak has also become a form of evaluation for the education system in Indonesia.

Davies and Graff's study (2005) found that a greater level of online interaction does not lead to better performance when it comes to achieving final grades. The students who fail at learning tend to interact less and are less able to utilise the digital learning media. This kind of interaction shows that online media cannot yet be positioned as an optimal learning method, particularly as there are those who are passive to the learning method itself. Social media such as Reddit can also be used as an online learning media in which there are questions and answers, debates, corrections and presenting information to other users (Haythornthwaite et al., 2018).

\subsection{Problems Experienced by the Students during Online Learning}

Online learning is more flexible despite the limited supporting facilities. The lecturers and students are not bound by time and place when it comes to discussing the lessons. Although they do not meet using livestreaming, the lecturers can share explanatory videos or study materials in the form of text through e-mails or other applications. Online learning makes it easy for the teachers to send material anywhere at any time, and the students can also follow the learning process anywhere and at any time while connected to the internet (Wardoyo, 2016; Bourne, Harris, \&Mayadas, 2005). This learning can be done in Madura but it is indeed necessary to make even better efforts to implement this policy.

A study conducted by Marks, Sibley and Arbaugh (2005) stated that various online media that can be used as learning tools such as streaming media, PowerPoint and hyperlinks. They also found out the factors influencing the quality of online learning such as the quality of the distance learning (due to work, family flexibility and geography) and the student's personal characteristics (experience and gender). In addition to PowerPoint, another media used as a learning tool is Prezi, one of the applications that is similar to 
PowerPoint that qualifies as a learning medium because Prezi's validity is secure, practical, and effective (Hartini et al., 2017; Akgün, Babur, \& Albayrak, 2016; Rodhi \& Wasis, 2014). The convenience offered by online learning actually has a big impact on both the students and teachers who are truly able to make the most of it, particularly due to the vast choice of streaming applications that are currently spreading across various platforms. Wikan Sakarinto, I Made Andi Arsana and Agus Affianto are some of the teachers from Indonesia who have used social media a lot, so that they are close to their students. Wikan Sakarinto, for example, has a Youtube channel that can be accessed by his students relating to the study materials.

Furthermore, there are also problems with online learning among the families of the students. At the time of the Covid-19 outbreak, the government had not yet blocked inter-city mobility. The students chose to return to their hometowns rather than to stay in their rental houses. In the end, they had to learn from home. However, this becomes a problem for some students as the atmosphere at home is not the same as where they live in the rental house near campus. Staying at home means that they do more homework and help their parents at work, so they sometimes neglect their tasks. In this case, the family has an influence on the learning process of the students.

A study conducted by Yeboah and Smith (2016) explained that satisfaction and the use of social media have no relationship with the participants' academic performance. However, there is an indication that flexibility and the convenience of time, self-confidence, a lack of support, independent learning skills and language/linguistic differences can affect the way that students learn. In the case of the learning system in Indonesia, the community still considers social media to be a playground. This is influenced by the old assumptions that learning should involve books and that books are a source of knowledge. Meanwhile, education has experienced a shift in values and the methods of learning used from the point when e-books were first introduced. However, people are still comfortable using conventional media compared to electronic devices as a learning support.

Therefore the new learning system is not accompanied by a new perspective. At a time when the development of education in various countries is advancing rapidly, rural and remote communities are still faced with technical problems. This subsequently causes a problem in that online learning still cannot be utilised as an alternative to conventional learning.

In addition, society in some of the rural and remote regions of Madura Island still cannot understand that learning can take place anywhere and at any time. They still cannot "let go" of the teacher figure. For traditional societies, the teacher becomes a perfect example when they appear in front of the class, wearing a uniform, explaining the lesson, and interacting with the students face to face. This condition is different from the other countries that present teachers in a digital form. Even though Indonesia has developed an online-based academic course platform, this application has not yet attracted a large number 
of students. As shown in Table 6, the students feel uncomfortable using online media to access learning material for various reasons.

Table 6: Reasons for online learning not benefiting the students $(\mathrm{N}=274)$

\begin{tabular}{|c|c|c|c|c|c|c|}
\hline \multirow{3}{*}{$\begin{array}{c}\text { Reasons for online } \\
\text { learning not } \\
\text { benefiting the } \\
\text { students }\end{array}$} & \multicolumn{4}{|c|}{ Gender } & \multirow[t]{3}{*}{ Frequency } & \multirow[t]{3}{*}{ Percentage } \\
\hline & \multicolumn{2}{|c|}{ Female } & \multicolumn{2}{|c|}{ Male } & & \\
\hline & F & $\%$ & $F$ & $\%$ & & \\
\hline $\begin{array}{l}\text { The lecturer cannot } \\
\text { explain things directly } \\
\text { in the class physically }\end{array}$ & 40 & $14,60 \%$ & 30 & $10,95 \%$ & 70 & $25.48 \%$ \\
\hline $\begin{array}{lr}\text { Students } & \text { are } \\
\text { burdened } & \text { with } \\
\text { assignments } & \end{array}$ & 53 & $19,35 \%$ & 21 & $7,66 \%$ & 74 & $26.83 \%$ \\
\hline $\begin{array}{l}\text { Need to buy an } \\
\text { internet quota }\end{array}$ & 27 & $9,85 \%$ & 38 & $13,87 \%$ & 65 & $23.90 \%$ \\
\hline $\begin{array}{l}\text { Signal is difficult to } \\
\text { access in certain areas }\end{array}$ & 23 & $8,39 \%$ & 42 & $15,33 \%$ & 65 & $23.79 \%$ \\
\hline \multicolumn{5}{|c|}{ Total } & 274 & $100 \%$ \\
\hline
\end{tabular}

Source: Primary Data

Table 6 shows that for some of the respondents, conventional learning has not been able to be replaced by other methods. Online learning is considered to be something that is not yet effective and efficient, so they feel that online learning does not benefit them at all. The students are not familiar with the use of online learning media and they also feel that online learning is increasingly overwhelming the students with many tasks. Meanwhile, the male students revealed that the signal is difficult to access in remote areas. Rahma (age 21, female student) said the following:

"There are many assignments given by lecturers. Even though during the pandemic I am at home and have to help my parent do household chores because I am girl".

Indonesian society adheres to a patriarchal culture where there is a sexual division of labour. As revealed by Rahma, she felt burdened by the domestic chores that were imposed on her because she was a woman. Therefore she felt that the large number of lecture assignments from the lecturers increased her life burden. This is in contrast to men who are generally free from domestic work. As expressed by the parents of Andi (age 20, student) and Dony (age 20, student), the male students complained more about the internet signal and quota fees that had to be bought.

"But the problem is the internet signal. The signal is sometimes not smooth, because our house is in the remote area". (Dew, age 55, parent of Andi).

"My child buys internet quota more often. Online learning looks simple, but it costs a lot for the internet". (Sur, 57, parent of Dony).

A study conducted by Stiller and Köster (2016) found that the burden experienced by students when using online media as a learning tool includes multidimensional learning task models, differences in technological 
understanding, and a lack of knowledge of how to use online media. Since there is a learning policy at home, it makes the teachers unable to provide direct material and control their students, so the learning process is left up to the parents and the teacher will make an evaluation afterwards. This is not appropriate in some communities in Indonesia, especially among the lowermiddle class or upper class where the parents are very busy at work. They therefore do not pay attention to their children's learning hours.

Previous studies have explained that one of the supportive factors of online learning is the use of infographics. These are visualisation tools used to increase retention and understanding in terms of student attraction. This is because infographics are a common visual medium used for presenting the learning material (Elena-Gallagher et al., 2017; Matrix \& Hodson, 2014; Akhamd et al., 2017). Unfortunately, not all teachers and lecturers can present infographics, so their online learning seems stiff and monotonous.

The Covid-19 outbreak has had an important impact on education in Indonesia. Previous conventional learning has turned into online learning in order to prevent the spread of the virus. The policy applied in all schools and universities in Indonesia still faces a number of obstacles. Although almost all regions in Indonesia are covered by internet services, the community still faces obstacles when accessing online education.

Not all college students like online learning because of the ineffective methods involved. Social, economic and cultural factors are important indicators that online learning has not been able to be applied in a number of regions in Indonesia including Madura Island. In addition, the community is not ready to welcome the latest learning methods and it is still comfortable using the old methods.

\section{Conclusions and Implications}

This study concludes that the online learning policies in some regions of Indonesia are still encountering a number of obstacles. Not only are these technical obstacles such as the availability of learning facilities but also the social and cultural conditions of Indonesian society that have not been able to follow this new system quickly. It takes time and consistent practice. This policy needs to be supported by the provision of facilities both technical and in the form of human resources in order to make the education system in Indonesia even better.

The research implications are good starting points to use to conduct similar studies determining the appropriate learning delivery modality in such trying times. Online learning is a necessity especially in difficult times like the current Covid-19 pandemic. Efforts are needed to maximise the progress of learning.

Educational institutions should pay attention to the fact that online learning requires internet access in order for the student to be connected. Meanwhile, there are many students in Indonesia who are constrained by the cost of doing this, including students on Madura Island. In addition, not all areas on Madura 
Island can receive an internet signal well. There are remote areas that experience a limited internet signal. This is what hampers online learning.

Because they are not used to it, students find it difficult to study online. In this case, the lecturers and students can innovate to create a learning atmosphere that is not boring and effective in terms of the knowledge transfer method used. Changes in the behaviour of both lecturers and students is needed so then the educational goals can be optimally realised. In addition, educational institutions also need to make their distance learning innovations more effective and efficient.

This study produce recommendations regarding online learning policies. The Ministry of Education and Culture of Indonesia needs to pay attention when dealing with the problems of access to education in rural and remote areas. The central and regional governments should provide adequate facilities and access to education, especially in rural areas inclusive of financial assistance, especially for the poor who have difficulty accessing the internet.

\section{References}

Abrami, P. C., Bernard, R. M., Bures, E. M., Borokhovski, E., \& Tamim, R. M. (2011). Interaction in distance education and online learning: using evidence and theory to improve practice. Journal of Computing in Higher Education, 23(2-3), 82-103.

Agostinho, S., Bennett, S., Lockyer, L., \& Harper, B. (2011). The future of learning design. Learning, Media and Technology, 36(2), 97-99.

Ahmad, L., Sosa, M., \& Musfy, K. (2020). Interior Design Teaching Methodology During the Global COVID-19 Pandemic. Interiority, 3(2), 163-184. doi:10.7454/in.v3i2.100

Akgün, O. E., Babur, A., \& Albayrak, E. (2016). Effects of lectures with Powerpoint or Prezi presentations on cognitive load, recall, and conceptual learning. International Online Journal of Educational Sciences, 8(3), 1-11.

Annad, D. (2008). Learning efficacy and cost-effectiveness of print versus e-book instructional material in an introductory financial accounting course. Journal of Interactive Online Learning, 7(2), 152-164.

Arista, F. S., \& Kuswanto, H. (2018). Virtual physics laboratory application based on the android smartphone to improve learning independence and conceptual understanding. International Journal of Instruction, 11(1), 1-16.

Batt, A. M., \& Cummins, N. M. (2016). E-learning on the road: online learning and social media for continuous professional competency. Irish Journal of Paramedicine, 1(1), $1-9$.

Bolliger, D. U., Supanakorn, S., \& Boggs, C. (2010). Impact of podcasting on student motivation in the online learning environment. Computers $\mathcal{E}$ Education, 55(2), 714-722.

Bound, H. (2010). Developing quality online dialogue: Dialogical inquiry. International Journal of Teaching and Learning in Higher Education, 22(2), 107-119.

Bourne, J., Harris, D., \& Mayadas, F. (2005). Online engineering education: Learning anywhere, anytime. Journal of Engineering Education, 94(1), 131-146.

Brown, C., Czerniewicz, L., \& Noakes, T. (2015). Online content creation: looking at students' social media practices through a Connected Learning lens. Learning, Media and Technology, 41(1), 140-159.

Brownson, S. M. (2014). Embedding social media tools in online learning courses. San Francisco, USA: The Clute Institute International Business \& Education Conferences. 
Chau, C. (2010). YouTube as a participatory culture. New Directions for Youth Development, 2010(128), 65-74.

Clerkin, K., \& Simon, Y. (2014). College for America: Student-Centered, CompetencyBased Education. Change: The Magazine of Higher Learning, 46(6), 6-13. doi:10.1080/00091383.2014.969141

Crick, T., Knight, C., Watermeyer, R., \& Goodall, J. (2020). The Impact of COVID-19 and "Emergency Remote Teaching" on the UK Computer Science Education Community. UKICER '20: United Kingdom \& Ireland Computing Education Research Conference, 31-37. doi:10.1145/3416465.3416472

Dabbagh, N., \& Kitsantas, A. (2012). Personal Learning environments, social media, and self-regulated learning: A natural formula for connecting formal and informal learning. The Internet and Higher Education, 15(1), 3-8.

Davies, J., \& Graff, M. (2005). Performance in e-learning: online participation and student grades. British Journal of Educational Technology, 36(4), 657-663.

Elena-Gallagher, S., O’Dulain, M., O'Mahony, N., Kehoe, C., McCarthy, F., \& Morgan, G. (2017). Instructor-provided summary infographics to support online learning. Educational Media International, 54(2), 129-147.

Farooq, M. U., \& Javid, C. Z. (2012). Attitude of students towards E-learning: A study of English language learners at Taif University English Language Centre. NUML Journal of Critical Inquiry, 10(2).

Fortune, M. F., Spielman, M., \& Pangelinan, D. T. (2011). Students' perceptions of online or face-to-face learning and social media in hospitality, recreation and tourism. MERLOT Journal of Online Learning and Teaching, 7(1), 1-16.

Friedman, L. W., Friedman, H. H. (2020). Using social media technologies to enhance online learning. Journal of Educators Online, 10(1), 1-22.

Greenhow, C., \& Lewin, C. (2015). Social media and education: reconceptualizing the boundaries of formal and informal learning. Learning, Media and Technology, 41(1), 6-30.

Greenhow, C., \& Robelia, B. (2009). Informal learning and identity formation in online social networks. Learning, Media and Technology, 34(2), 119-140.

Gutmann, J., Kühbeck, F., Berberat, P. O., Fischer, M. R., Engelhardt, S., \& Sarikas, A. (2015). Use of learning media by undergraduate medical students in pharmacology: A prospective cohort study. PLOS ONE, 10(4), e0122624. doi:10.1371/journal.pone.0122624

Hamilton, L. A., Franks, A., Heidel, R., McDonough, S. K. L., \& Suda, K. J. (2016). Assessing the value of online learning and social media in pharmacy education. American Journal of Pharmaceutical Education, 80(6), 1-6.

Hansch, A., Hillers, L., McConachie, K., Newman, C., Schildhauer, T., \& Schmidt, P. (2015). Video and online learning: Critical reflections and findings from the field. SSRN Electronic Journal. doi:10.2139/ssrn.2577882

Hartini, S., Misbah, Dewantara, D., Oktovian, R.A., \& Aisyah, N. (2017). Developing learning media using online Prezi into materials about optical equipments. Jurnal Pendidikan IPA Indonesia, 6(2), 313-317.

Hartsell, T., \& Yuen, S. C. Y. (2006). Video streaming in online learning. AACE Journal, 14(1), 31-43.

Haythornthwaite, C., Kumar, P., Gruzd, A., Gilbert, S., Esteve del Valle, M., \& Paulin, D. (2018). Learning in the wild: coding for learning and practice on Reddit. Learning, Media and Technology, 43(3), 219-235.

Heinich, R., Molenda, M., Russell, J. D., \& Smaldino, S. E. (1982). Instructional Media and Technologies for Learning (7th Edition). New Jersey: Prentice - Hall Inc.

Herayanti, L., Fuaddunnazmi, M., \& Habibi. (2015). Pengembangan media pembelajaran berbasis Moodle pada mata kuliah fisika dasar [Development of Moodle-based 
learning media in basic physics courses]. Jurnal Pendidikan Fisika dan Teknologi, 1(3), 205-209.

Hollis, R. B., \& Was, C. A. (2016). Mind wandering, control failures, and social media distractions in online learning. Learning and Instruction, 42, 104-112.

Horzum, M. B. (2015). Interaction, structure, social presence, and satisfaction in online learning. Eurasia Journal of Mathematics, Science \& Technology Education, 11(3), 505512.

Irwansyah, F. S., Yusuf, Y. M., Farida, I., \& Ramdhani, M. A. (2017). Augmented Reality (AR) technology on the android operating system in chemistry learning. The 2nd Annual Applied Science and Engineering Conference (AASEC 2017), 24 August 2017 (Vol. 288). Bandung, Indonesia. doi:10.1088/1757-899X/288/1/012068

Junco, R., Heiberger, G., \& Loken, E. (2010). The effect of Twitter on college student engagement and grades. Journal of Computer Assisted Learning, 27(2), 119-132.

Kaler, C. B. (2012). A Model of Successful Adaptation to Online Learning for CollegeBound Native American HIgh School Students. Multicultural Education \& Technology Journal, 6(2), 60-76. doi:10.1108/17504971211236245

Kirkwood, A., \& Price, L. (2013). Technology-enhanced learning and teaching in higher education: what is "enhanced" and how do we know? A critical literature review. Learning, Media and Technology, 39(1), 6-36.

Kobayashi, M. (2017). Students' media preferences in online learning. Turkish Online Journal of Distance Education, 18(3), 4-15.

Kock, N., Verville, J., \& Garza, V. (2007). Media naturalness and online learning: Findings supporting both the significant- and no-significant-difference perspectives. Decision Sciences Journal of Innovative Education, 5(2), 333-355.

Kruse, N. B., \& Veblen, K. K. (2012). Music teaching and learning online: Considering YouTube instructional videos. Journal of Music, Technology and Education, 5(1), 77-87.

Kuang-Chih L., \& Kriegman, D. (n.d.). Online learning of probabilistic appearance manifolds for video-based recognition and tracking. 2005 IEEE Computer Society Conference on Computer Vision and Pattern Recognition (CVPR'05), 20-25 June 2005. San Diego, USA. doi:10.1109/cvpr.2005.260

Lin, C. C., \& Polaniecki, S. (2009). From media consumption to media production: Applications of YouTube $^{\mathrm{TM}}$ in an eighth-grade video documentary project. Journal of Visual Literacy, 28(1), 92-107.

Liu, Y. (2005). Effects of online instruction vs. traditional instruction on students' learning. International Journal of Instructional Technology and Distance Learning, 2(3), 57-64.

Madge, C., Meek, J., Wellens, J., \& Hooley, T. (2009). Facebook, social integration and informal learning at university: "It is more for socialising and talking to friends about work than for actually doing work." Learning, Media and Technology, 34(2), 141-155.

Marks, R. B., Sibley, S. D., \& Arbaugh, J. B. (2005). A structural equation model of predictors for effective online learning. Journal of Management Education, 29(4), 531-563.

Martono, K. T., \& Nurhayati, O. D. (2014). Implementation of android based mobile learning application as a flexible learning media. International Journal of Computer Science Issues, 11(3), 168-174.

Matrix, S., \& Hodson, J. (2014). Teaching with infographics: practising new digital competencies and visual literacies. Journal of Pedagogic Development, 3(2), 17-27.

Megan, P. (2015). 'Create a better online you': Designing online learning resources to develop undergraduate social media skills. In Field, R \& Nelson, K (Eds.) Proceedings of the 2015 Students Transitions Achievement Retention and Success 
(STARS) Conference, (pp. 1-5). The Office for Learning and Teaching (OLT), Australia.

Moghavvemi, S., Sulaiman, A., Jaafar, N. I., \& Kasem, N. (2018). Social media as a complementary learning tool for teaching and learning: The case of youtube. The International Journal of Management Education, 16(1), 37-42.

Moore, J. L., Dickson-Deane, C., \& Galyen, K. (2011). e-Learning, online learning, and distance learning environments: Are they the same? The Internet and Higher Education, 14(2), 129-135. doi:10.1016/j.iheduc.2010.10.001

Moran, M., Seaman, J., \& Tinti-Kane, H. (2011). Teaching, learning, and sharing: How today's higher education faculty use social media. Babson Survey Research Group.

Nacu, D. C., Martin, C. K., Pinkard, N., \& Gray, T. (2014). Analyzing educators' online interactions: a framework of online learning support roles. Learning, Media and Technology, 41(2), 283-305.

Peppler, K. A., \& Kafai, Y. B. (2007). From SuperGoo to scratch: Exploring creative digital media production in informal learning. Learning, Media and Technology, 32(2), 149-166.

Power, M. (2008). The emergence of a blended online learning environment. MERLOT Journal of Online Learning and Teaching, 4(4), 503-514.

Prastiyo, W., Djohar, A., \& Purnawan. (2018). Development of Youtube integrated Google Classroom based E-learning media for the light-weight vehicle engineering vocational high school. Jurnal Pendidikan Vokasi, 8(1), 53-66.

Putranti, N. (2013). Cara membuat media pembelajaran online menggunakan Edmodo [How to make online learning media using Edmodo]. Jurnal Pendidikan Informatika dan Sains, 2(2), 139-147.

Rodhi, M. Y., \& Wasis. (2014). Pengembangan media pembelajara berbasis Prezi untuk meningkatkan keterampilan berpikir kritis pada materi kalor [Development of Prezi-based learning media to improve critical thinking skills on heat material]. Jurnal Inovasi Pendidikan Fisika (JIPF), 3(2), 137-142.

Rovai, A. P., \& Jordan, H. (2004). Blended learning and sense of community: a comparative analysis with traditional and fully online graduate courses. The International Review of Research in Open and Distributed Learning, 5(2). https:// doi.org/10.19173/irrodl.v5i2.192.

Rusman. (2011). Pembelajaran Berbasis Teknologi Informasi dan Komunikasi, Mengembangkan Profesionalitas Guru [Information and Communication Technology Based Learning, Developing Teacher Professionalism]. Jakarta: PT. Rajagrafindo Persada.

Sagala, S. (2008). Konsep dan Makna Pembelajaran [Learning Concepts and Meanings]. Bandung: Alfabeta.

Salmon, G., Ross, B., Pechenkina, E., \& Chase, A.M. (2015). The space for social media in structured online learning. Research in Learning Technology, 23, 1-14.

Selwyn, N. (2009). Faceworking: Exploring students' education-related use of Facebook. Learning, Media and Technology, 34(2), 157-174.

Selwyn, N., \& Stirling, E. (2015). Social media and education ... now the dust has settled. Learning, Media and Technology, 41(1), 1-5.

Schoenfeld-Tacher, R., McConnell, S., \& Graham, M. (2001). Journal of Science Education and Technology, 10(3), 257-265.

Shen, C., Kuo, C. J., \& Minh Ly, P. T. (2017). Analysis of social media influencers and trends on online and mobile learning. The International Review of Research in Open and Distributed Learning, 18(1). doi:10.19173/irrodl.v18i1.2640

Stiller, K. D., \& Köster, A. (2016). Learner attrition in an advanced vocational online training: The role of computer attitude, computer anxiety, and online learning experience. European Journal of Open, Distance and E-Learning, 19(2), 1-14.

Susan, M., \& Tony. (1995). Learning to Teach in The Secondary School. London: Routledge. 
Tan, E. (2013). Informal learning on YouTube: Exploring digital literacy in independent online learning. Learning, Media and Technology, 38(4), 463-477.

Thoms, B., \& Eryilmaz, E. (2014). How media choice affects learner interactions in distance learning classes. Computers \& Education, 75, 112-126.

Thomson, A., \& Bridgstock, R. (2014). 'Teachers flipping out' beyond the online lecture: Maximising the educational potential of video. Journal of Learning Design, 7(3), 67-78.

Trianto. (2007). Model-Model Pembelajaran Inovatif Berorientasi Kontstruktivistik. Konsep, Landasan Teoritis-Praktis dan Implementasinya [Constructivist Oriented Innovative Learning Models. Concept, Theoretical-Practical Basis and Its Implementation]. Jakarta: Prestasi Pustaka.

Veletsianos, G. (2011). Higher education scholars' participation and practices on Twitter. Journal of Computer Assisted Learning, 28(4), 336-349.

Wardoyo, C. (2016). Developing learning media based on e-learning on accounting subject for senior high school students. Dinamika Pendidikan, 11(2), 84-93.

Whittaker, A. L., Howarth, G. S., \& Lymn, K. A. (2014). Evaluation of Facebook to create an online learning community in an undergraduate animal science class. Educational Media International, 51(2), 135-145.

Yang, J. C., Quadir, B., Chen, N. S., \& Miao, Q. (2016). Effects of online presence on learning performance in a blog-based online course. The Internet and Higher Education, 30, 11-20.

Yeboah, A. K., \& Smith, P. (2016). Relationships between minority students online learning experiences and academic performance. Online Learning, 20(4), 1-26.

Yuan, L., Powell, S., \& Olivier, B. (2014). Beyond MOOCs: Sustainable online learning in institutions. USA: Centre for Educational Technology, Interoperability and Standards. 